\title{
Sweetpotato (SP-30) Flakes: Process Optimization and Moisture Adsorption Isotherm Studies
}

\author{
Julie D. Tan, Daniel Leslie S. Tan and Adrian C. Alumbro \\ Philippine Root Crop Research and Training Center, Visayas State University, \\ Baybay City, Leyte, 6521-A Philippines
}

\begin{abstract}
Sweetpotato is one of the predominant crops grown by local farmers in the marginal uplands of Brgy. Linao, Sitio Batuan, Inopacan, Leyte. The need to produce quality food products from sweetpotato is a continuing challenge to open new opportunities for farmers and entrepreneurs alike. This study aimed to determine the potential of sweetpotato var.SP30 for flake production and conduct moisture adsorption isotherm studies. Two screening processes were made using the 7-variable 8-run Plackett-Burman design while a face centered Central Composite Design (CCD) was employed during optimization. Sensory evaluation results were subjected to response surface regression (RSREG) analyses to generate optimum processing condition(s). Moisture adsorption studies were carried out to determine the nature of the product isotherm based on Brunauer-Deming-Deming-Teller (BDDT) classifications. Fitting of data was done using the Bruanauer-Emmett and Teller (BET) and Guggenheim-Anderson de Boer (GAB) models to determine the amount of adsorbed moisture in the product during storage at different temperature levels.

Screening results identified Drying time (Dt), Drying Temperature (DT) and Oven Toasting time (OTt) as the critical processing variables. A set of combinations of Dt (min.), DT $\left({ }^{\circ} \mathrm{C}\right)$, and OTt (min.) were generated as a result of the optimization. These combinations were 75-50-20, 80-50-20, 80-50-18, 85-50-20 and 90-50-20. Calculated values for the mass fraction of adsorbed water in the monolayer $\left(\mathrm{W}_{\mathrm{mB}}\right.$ and $\left.\mathrm{W}_{\mathrm{mG}}\right)$ at $30^{\circ} \mathrm{C}$, $40^{\circ} \mathrm{C}$ and $50^{\circ} \mathrm{C}$ are $0.0971,0.1311,0.0591$ and $0.1046,0.2447$ and 0.2224 respectively (expressed ing/100 $\mathrm{g} \mathrm{H}_{2} \mathrm{O}$ )

Sweetpotato (var. SP30) was found suitable for flake production. Moisture adsorption isotherm of sweetpotato flakes was sigmoid in shape and classified as type II in the BDDT classification. $\mathrm{W}_{\mathrm{m}}$ values for both BET and GAB were found to follow the relationship $\mathrm{W}_{\mathrm{mB}}<\mathrm{W}_{\mathrm{mG}}($ Timmerman, 2003).
\end{abstract}

Key Words: sweetpotato flakes, variable screening, optimization, moisture adsorption

Correspondence : J.D. Tan Address: Philippine Root Crop Research and Training Center, Visayas State University, Baybay City, Leyte, 6521-A Philippines Email: jdtan7177@yahoo.com

DOI: 10.32945/atr36s17.2014 
Tan et al.

\section{INTRODUCTION}

The Philippine Root Crop Research and Training Center (PhilRootcrops) at the Visayas State University is mandated to develop novel food products from the different sweetpotato varieties that could compete in the global market. New varieties, which are highly nutritious, are being developed and propagated especially the purple and orange varieties high in anthocyanin and carotene contents. These varieties are known to have antioxidant properties. The development of novel food products from sweetpotato is one way of addressing the country's Processed Food Sector Science and Technology Roadmap for 2009-2014 (Estillore, 2009).

Sweetpotato is one of the most nutritious tuber crops grown in most tropical countries. It is a high-calorie crop and a cheap source of important nutrients and vitamins. More recently, sweetpotato was reported to have low glycemic index. Because of this, sweetpotato is believed to play a significant role in addressing health problems on the increasing incidence of degenerative diseases especially diabetes. Because of its low glycemic index (GI), sweetpotato and other rootcrops can serve as alternative energy foods especially for diabetic people in addition to its vitamins and micronutrient contents (Trinidad et al., 2009). Gopalakrishnan et al (2011) demonstrated the potential of sweetpotato as low glycemic food. Whey protein concentrate fortified with sweetpotato possess the lowest rapidly digested starch and the highest resistant starch content. In combination with legumes, sweetpotato can form an ideal food to combat protein calorie malnutrition, which is so widespread in almost all developing countries (Winarno, 1982). Olayiwola et al (2010) reported that sweetpotato in various dish preparations can improve nutritional status of the consumers.

A number of food products have been developed from sweetpotato ranging from local or traditional to sophisticated or novel products. It is usually boiled, baked, steamed, fried, candied or pureed. It is also used in the production of industrial products such as syrup, alcohol and related compounds, vitamins, protein-rich pulp, food yeast and silage (Edmund and American, 1971). Sweetpotato in dehydrated forms has gained importance in its preservation. Dehydrated sweetpotato products such as chips, flakes, and flour are in stable form and thus, could maintain their quality even for years if properly stored at their safe moisture level. Flakes offer excellent convenience and can be easily handled or stored. 
Sweetpotatoes are abundantly produced in the country but not fully utilized for foods and other industrial uses. A greater percentage of the fresh crops are easily infested with weevil and diseases at the field or even at prolonged storage. Processing of sweetpotato into dried forms will not only minimize spoilage and losses but offers quality and variety of products from sweetpotato. With the different sweetpotato varieties that are now available in the country particularly the developed varieties from PhilRootcrops, there will be an assurance for abundant supply of raw materials for flake production. Most of these sweetpotatoes are anthocyanin and carotene-rich varieties. As inexpensive source of energy and nutrients, it is no doubt that sweetpotato is an answer to malnutrition problem of the country. This crop, however, must be in a form that will be stable, palatable and attractive to consumers especially to the children who are the main target group in combating malnutrition problem. The sweetpotato in flake form is a ready-to-eat, stable and in convenient form that can be immediately consumed. It can also be used in the preparation of sweetpotato fries, mashed sweetpotato, and deep fat fried snacks. Among children, the flakes can be so inviting as snack food or breakfast cereal.

As health benefits of sweetpotato are recognized by food researchers, dieticians and nutritionists, researches more on product development, nutritional and functional evaluation are being conducted in the Philippines and other countries. Consumption of this crop would undoubtedly help improve the health of individuals from children to adults. Raw sweetpotato tubers are also excellent sources of carotenoids, potassium, iron, calcium, phenolic compounds and simple sugars such as sucrose, glucose and fructose (Antonio et al., 2011).

The Philippine Root Crop Research and Training Center has developed a number of food products from sweetpotato, namely; pickles, wine and sweetpotato-flavored acidophilus milk (Tan and Forio, 1997a, 1997b and Perez and Tan, 2006). With 25\% substitution of wheat flour with sweetpotato in madiga, a local wheat-based bread of Niger Delta Regions of Southern Nigeria, an increase in the energy, Vitamin A, B6, C and magnesium contents was observed (Idolo, 2011). In Southern Kyushu, the manufacture of starch and shochu from sweetpotato produces distillation residue which is still considered as foodstuff since it is rich in dietary fibers and anti-oxidant substances (Suganuma et al., 2008). 


\section{MATERIALS AND METHODS}

\section{Variable Screening}

Two screening processes were conducted using the 7-variable 8-Run Plackett-Burman design using different treatments shown in Tables 1 and 2. Results were subjected to sensory evaluation using the 9-point Hedonic scale and were analyzed using STATISTICA version 6.0. The top three significant variables from the second screening were used in the optimization process.

Table 1. Variable levels for the $1^{\text {st }}$ screening.

\begin{tabular}{cccccccc}
\hline Treatment & $\begin{array}{c}\text { Dilution } \\
\text { Ratio } \\
\text { (Puree:H2O) }\end{array}$ & $\begin{array}{c}\text { Enzyme } \\
\text { Activation } \\
\text { time (EAt) }\end{array}$ & $\begin{array}{c}\text { Enzyme } \\
\text { Activation } \\
\text { Temp. } \\
\text { (EAt) }\end{array}$ & $\begin{array}{c}\text { Oven } \\
\text { Toasting } \\
\text { time } \\
\text { (OTt) }\end{array}$ & $\begin{array}{c}\text { Oven } \\
\text { Toasting } \\
\text { Temp. } \\
\text { (OTT) }\end{array}$ & $\begin{array}{c}\text { Dummy } \\
1\end{array}$ & $\begin{array}{c}\text { Dummy } \\
2\end{array}$ \\
\hline 1 & $2: 1$ & 60 & 70 & 90 & 150 & 1 & 1 \\
2 & $2: 1 / 2$ & 60 & 70 & 120 & 100 & 2 & 1 \\
3 & $2: 1 / 2$ & 20 & 70 & 120 & 150 & 1 & 2 \\
4 & $2: 1$ & 20 & 60 & 120 & 150 & 2 & 1 \\
5 & $2: 1 / 2$ & 60 & 60 & 90 & 150 & 2 & 2 \\
6 & $2: 1$ & 20 & 70 & 90 & 100 & 2 & 2 \\
7 & $2: 1$ & 60 & 60 & 120 & 100 & 1 & 2 \\
8 & $2: 1 / 2$ & 20 & 60 & 90 & 100 & 1 & 1 \\
\hline
\end{tabular}

* Time (minutes); Temperature $\left({ }^{\circ} \mathrm{C}\right)$

Table 2. Variable levels for the $2^{\text {nd }}$ screening.

\begin{tabular}{cccccccc}
\hline Treatment & $\begin{array}{c}\text { Enzyme } \\
\text { Activation } \\
\text { time (EAt) }\end{array}$ & $\begin{array}{c}\text { Enzyme } \\
\text { Activation } \\
\text { Temp. } \\
\text { (EAt) }\end{array}$ & $\begin{array}{c}\text { Drying } \\
\text { time (Dt) }\end{array}$ & $\begin{array}{c}\text { Drying } \\
\text { Temp. } \\
\text { (DT) }\end{array}$ & $\begin{array}{c}\text { Oven } \\
\text { Toasting } \\
\text { time (OTt) }\end{array}$ & $\begin{array}{c}\text { Oven } \\
\text { Toasting } \\
\text { Temp. } \\
\text { (OTT) }\end{array}$ & Dummy \\
\hline 1 & 30 & 70 & 60 & 60 & 20 & 150 & 1 \\
2 & 10 & 70 & 60 & 100 & 10 & 170 & 1 \\
3 & 10 & 50 & 60 & 100 & 20 & 150 & 2 \\
4 & 30 & 50 & 30 & 100 & 20 & 170 & 1 \\
5 & 10 & 70 & 30 & 60 & 20 & 170 & 2 \\
6 & 30 & 50 & 60 & 60 & 10 & 170 & 2 \\
7 & 30 & 70 & 30 & 100 & 10 & 150 & 2 \\
8 & 10 & 50 & 30 & 60 & 10 & 150 & 1 \\
\hline
\end{tabular}

* Time (minutes); Temperature $\left({ }^{\circ} \mathrm{C}\right)$ 
Sweetpotato flakes: Process Optimization and Moisture Adsorption

The methods for the first and second screening are shown in Figures 1 and 2 . Based on the result of the first screening, drying was added in the second process.

\section{Optimization Experiment}

A "face centered" Central Composite Design (CCD) was used in the optimization process wherein the sensory results of the identified variables were subjected to response surface regression (RSREG) analyses using STATISTICA Version 6.0. Contour plots were made for all analyses of each run condition using STATISTICA version 5.0 to clarify the different effects of the factor variables on the response that was studied. Plots were superimposed and optimum conditions were determined.

Physico-chemical and Sensory Analyses of the Optimized Sweetpotato Flakes

Physico-chemical characteristics

Soluble solids (Hoover, 1967) - Twenty grams of flakes and $200 \mathrm{ml}$ of hot water were added to a $400-\mathrm{mL}$ beaker, stirred for 10 minutes with magnetic stirrer. After a 30-minute holding period, the mixture was filtered through No. 1 Whatman filter paper. The soluble solids in the filtrate were determined with a refractometer and the value obtained was multiplied by 10 to get the percentage of soluble solids in the flakes.

Bulk density (Manlan et. al, 1985) - The measurement of flake density was done based on a vibrated file. A 500-mL graduated cylinder was loosely filled with 100-g flakes and vibrated for 30 seconds on a vibrator. The bulk density was determined as the ratio of flakes weight per unit volume occupied.

Rehydration Ratio - Twenty grams of sweetpotato flakes was placed in a $600-\mathrm{mL}$ beaker and $200-\mathrm{mL}$ distilled water was added and then covered with a watch glass. The mixture was boiled for 10 minutes and rehydrated flakes was drained in a porous filter paper and weighed. Rehydration ratio was computed using the formula:

$$
\begin{aligned}
& \begin{array}{c}
\text { Rehydration Ratio }=M R / M \\
\text { Where }, \quad M R
\end{array} \quad \begin{array}{l}
M \text { weight of rehydrated flakes } \\
M=\text { weight of dried material }
\end{array}
\end{aligned}
$$




\section{Sensory characteristics}

The optimized product was evaluated based on color, aroma, texture, taste and general acceptability. A 9-point Hedonic Scale was used in evaluating the descriptive and acceptability of the sensory characteristics of the product.

\section{Sorption Isotherm Experiment}

Preparation of samples for sorption isotherm studies

Sweetpotato flakes were produced using the optimum process condition with the lowest cost established during the optimization experiment.

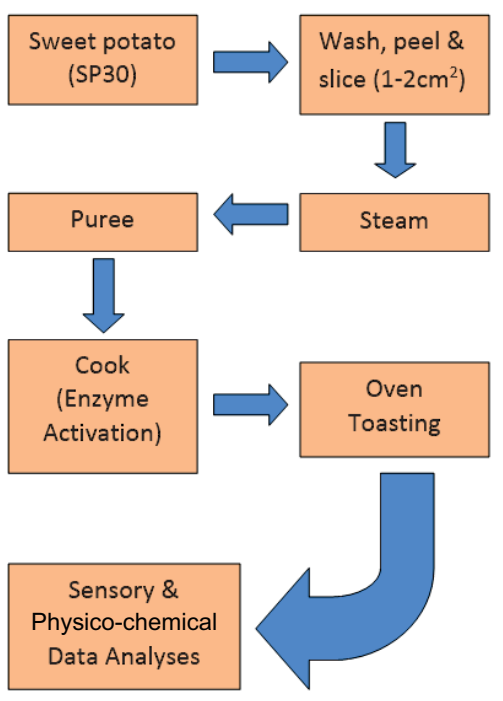

Figure 1. First screening process.

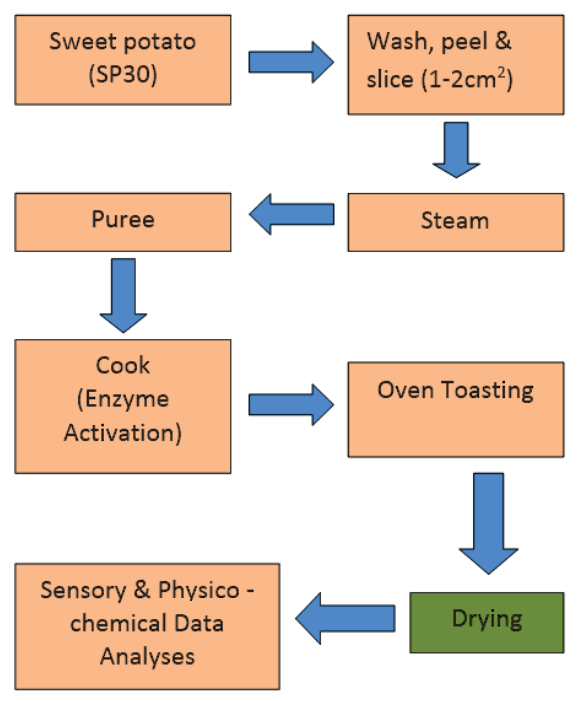

Figure 2. Second screening. process. 
Sweetpotato flakes: Process Optimization and Moisture Adsorption

Equilibrium Moisture Content (EMC)

A modified static gravimetric method was used in the determination of EMC (M. LIENDO-CARDENAS et al.). Erlenmeyer flasks containing saturated salt solution and stainless wire basket as the sample container were used (Figure 3).

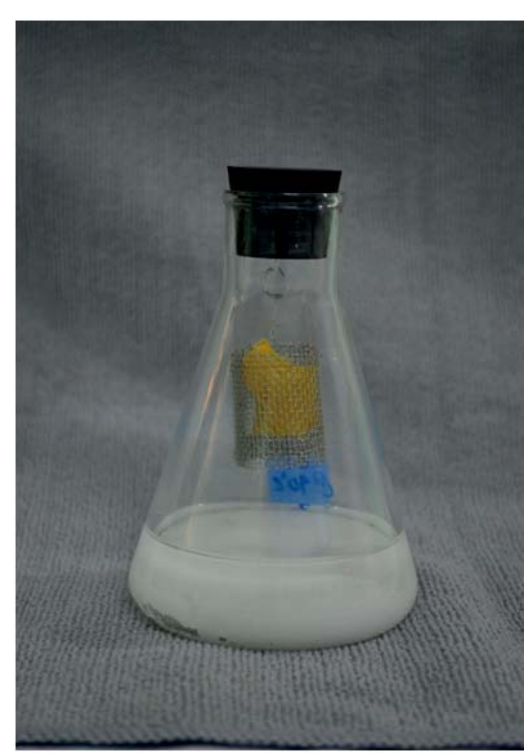

Figure 3. Experimental Set-up

A set of 8 solutions were selected giving a range of $0.06 \mathrm{~A}_{\mathrm{w}}$ to 0.9 $\mathrm{A}_{\mathrm{w}}$ (Table 3). The Erlenmeyer flasks were incubated (SHELL-LAB) at $30^{\circ} \mathrm{C}, 40^{\circ} \mathrm{C}$ and $50^{\circ} \mathrm{C}$ for up to 12 days. Equilibrium was manifested after obtaining constant sample weight in 3 consecutive weighing. Moisture content analysis was done using the vacuum oven method (AOAC, 1984). 
Sorption Isotherm Equations

BET and GAB parameter constants were calculated using the linearized forms of the equations as follows:

Brunauer-Emmett-Teller (BET)

$W=\left[C_{B} A_{w} /\left(1-A_{w}\right)\left[1+\left(C_{B}-1\right) A_{w}\right]\right] x$
$W_{m B}$

Where:

$$
\begin{aligned}
& \mathrm{Wm}_{\mathrm{B}}=\text { mass fraction of } \\
& \text { adsorbed water } \\
& \text { in the } \\
& \text { monolayer for } \\
& \text { B.E.T } \\
& \left(\mathrm{gH}_{2} \mathrm{O} / 100 \mathrm{~g}\right. \text { dry } \\
& \text { matter) } \\
& \mathrm{C}_{\mathrm{B}}=\text { B.E. } \mathrm{T} \text { constant } \\
& \mathrm{W}=\text { mass fraction of } \\
& \text { adsorbed water }
\end{aligned}
$$

Guggenheim-Anderson de Boer (GAB)

$\mathrm{W}=\left[\mathrm{C}_{\mathrm{G}} \mathrm{kA} \mathrm{A}_{\mathrm{w}} /\left(1-\mathrm{kA}_{\mathrm{w}}\right)\left[1+\left(\mathrm{C}_{\mathrm{G}}-1\right)\right.\right.$ $\mathrm{kA}_{\mathrm{w}}$ ]] $\times \mathrm{W}_{\mathrm{mG}}$

Where:

$$
\begin{aligned}
\mathrm{Wm}_{\mathrm{G}}= & \text { mass fraction of } \\
& \text { adsorbed water in } \\
& \text { the monolayer for } \\
& \text { G.A.B ( } \mathrm{gH}_{2} \mathrm{O} / 100 \mathrm{~g} \\
& \text { dry matter) }
\end{aligned}
$$

$\mathrm{C}_{\mathrm{G}}=\mathrm{G} \cdot \mathrm{A} \cdot \mathrm{B}$ constant

$\mathrm{K}=$ constant

$$
\begin{gathered}
\mathrm{W}=\text { mass fraction of } \\
\text { adsorbed water }
\end{gathered}
$$

Table 3. ERH for various salt solutions (Greenspan, 1977).

\begin{tabular}{llll}
\hline \multirow{2}{*}{ Salts Solutions } & \multicolumn{3}{l}{ Saturation Temperature, ${ }^{\circ} \mathrm{C}$} \\
\cline { 2 - 4 } & 30 & 40 & 50 \\
\hline $\mathrm{KOH}$ & $7.38 \pm 0.56$ & $6.26 \pm 0.35$ & $5.72 \pm 0.27$ \\
$\mathrm{LiCl}$ & $11.28 \pm 0.24$ & $11.21 \pm 0.21$ & $11.10 \pm 0.22$ \\
$\mathrm{MgCl}$ & $32.44 \pm 0.14$ & $31.60 \pm 0.13$ & $30.54 \pm 0.14$ \\
$\mathrm{KI}$ & $67.89 \pm 0.23$ & $66.09 \pm 0.23$ & $64.49 \pm 0.26$ \\
$\mathrm{NaCl}$ & $75.09 \pm 0.11$ & $74.68 \pm 0.13$ & $74.43 \pm 0.19$ \\
$\mathrm{KCl}$ & $83.62 \pm 0.25$ & $82.32 \pm 0.25$ & $81.2 \pm 0.31$ \\
$\mathrm{~K}_{2} \mathrm{SO}_{4}$ & $97.00 \pm 0.40$ & $96.41 \pm 0.38$ & $95.82 \pm 0.45$ \\
\hline
\end{tabular}




\section{RESULTS AND DISCUSSION}

\section{Variable Screening}

Results show that Dilution ratio and Oven Toasting time OTt gave negative effects on the product while Oven Toasting Temperature OTT gave a positive effect as indicated by the effect estimates (Table 4). A positive value means that an increase in the level of the corresponding variable positively affect the acceptability of the product while a negative value denotes a decrease in sensory acceptability rating of the product as the levels of variables are increased. Therefore, there is an increase in product overall acceptability if it were to be toasted at higher temperatures for a short period. In order to do this, a procedure prior to toasting should be integrated that would allow efficient moisture removal from the extruded puree. Only then can toasting at high temperature without compromising product quality can be attained. This analysis led to the identification of another variable that would allow toasting at the shortest possible time.

Table 4. Effect Estimates on the sensory acceptability of sweetpotato flakes.

\begin{tabular}{cccccc}
\hline \multirow{2}{*}{$\begin{array}{c}\text { Independent } \\
\text { Variables }\end{array}$} & \multicolumn{5}{c}{ Dependent Variables } \\
\cline { 2 - 6 } & Color & Aroma & Taste & Texture & Gen.Acc. \\
\cline { 2 - 6 } & $-0.6452^{*}$ & $-0.4435 \mathrm{~ns}$ & $-0.9758^{* *}$ & $-0.3145 \mathrm{~ns}$ & $-0.8306^{* *}$ \\
EAlution & $-0.2258 \mathrm{~ns}$ & $0.2661 \mathrm{~ns}$ & $0.6694^{*}$ & $0.0887 \mathrm{~ns}$ & $0.3468 \mathrm{~ns}$ \\
EAT & - & $0.0403 \mathrm{~ns}$ & $-0.5887^{*}$ & $-0.3629 \mathrm{~ns}$ & $-0.3790 \mathrm{~ns}$ \\
OTt & $-0.2581 \mathrm{~ns}$ & & & & \\
OTT & $-1.12960^{* *}$ & $-0.2984 \mathrm{~ns}$ & $-0.6532^{*}$ & $-0.0403 \mathrm{~ns}$ & $-0.7016^{*}$ \\
Dummy 1 & $0.0807 \mathrm{~ns}$ & $0.0887 \mathrm{~ns}$ & $0.3145 \mathrm{~ns}$ & $0.1855 \mathrm{~ns}$ & $0.4758^{*}$ \\
Dummy 2 & $-1.1774^{* *}$ & $-0.5726^{*}$ & $-0.9919^{* *}$ & $-0.5242^{*}$ & $-0.7661^{*}$ \\
\hline
\end{tabular}

$p \geq 0.05$ - Significant* $\quad p \geq 0.001$ - Highly Significant** ns - not significant *EA - Enzyme Activation, OT - Oven Toasting, t - time, T - Temperature

In the second screening, drying was integrated into the system. Results show that Dt, DT and OTt gave positive significant effects on the product and thus, were used in the optimization. 
Tan et al.

Table 5. Effect Estimates on the sensory acceptability of sweetpotato flakes ( $2{ }^{\text {nd }}$ Screening).

\begin{tabular}{cccccc}
\hline \multirow{2}{*}{$\begin{array}{c}\text { Independent } \\
\text { Variables }\end{array}$} & \multicolumn{5}{c}{ Dnd Screening } \\
\cline { 2 - 6 } & Color & Aroma & Taste & Texture & Gen.Acc. \\
\cline { 2 - 6 } & $0.5391 \mathrm{~ns}$ & $0.0000 \mathrm{~ns}$ & $-0.2266 \mathrm{~ns}$ & $-0.1719 \mathrm{~ns}$ & $-0.2969 \mathrm{~ns}$ \\
EAt & $0.4141^{*}$ & $-0.0938 \mathrm{~ns}$ & $-0.2578 \mathrm{~ns}$ & $-0.2969 \mathrm{~ns}$ & $0.1562 \mathrm{~ns}$ \\
EAT & $1.3672^{*}$ & $0.7031^{* *}$ & $0.6797^{*}$ & $1.5469^{* *}$ & $1.4219^{* *}$ \\
Dt & $-0.0547^{* *}$ & $0.8906^{* *}$ & $0.5391^{*}$ & $1.2656^{* *}$ & $0.9219^{* *}$ \\
DT & $0.1172 \mathrm{~ns}$ & $-0.1719 \mathrm{~ns}$ & $0.0547 \mathrm{~ns}$ & $0.9844^{* *}$ & $0.5938^{*}$ \\
OTt & $-0.5078^{*}$ & $0.0938 \mathrm{~ns}$ & $0.0391 \mathrm{~ns}$ & $0.3906 \mathrm{~ns}$ & $-0.1562 \mathrm{~ns}$ \\
OTT & 0.3516 & $-0.4531^{*}$ & $-0.3672 \mathrm{~ns}$ & $-1.2031^{* *}$ & $-0.7812^{* *}$ \\
Dummy & & & & &
\end{tabular}

$p \geq 0.05$ - Significant* $\quad p \geq 0.001$ - Highly Significant**

ns - not significant

*EA - Enzyme Activation, D - Drying, OT - Oven Toasting, $\mathrm{t}$ - time, $\mathrm{T}$ - Temperature

\section{Optimization}

Optimum conditions for sweetpotato flake production were obtained using Response Surface Regression analysis and by superimposing contour plots derived from sensory results. This was done by setting conditions producing an acceptability value of $\geq 7.0$ and superimposing two variables at a time while keeping the third variable constant. It should be noted that constant drying time at 75 minutes was not superimposed because of sensory scores $\leq 7.0$. The shaded region represents the values for consumer acceptance for a particular attribute of the product. This corresponds to score of $\geq 7.0$ which is described as "like moderately" in the 9 point Hedonic scale.

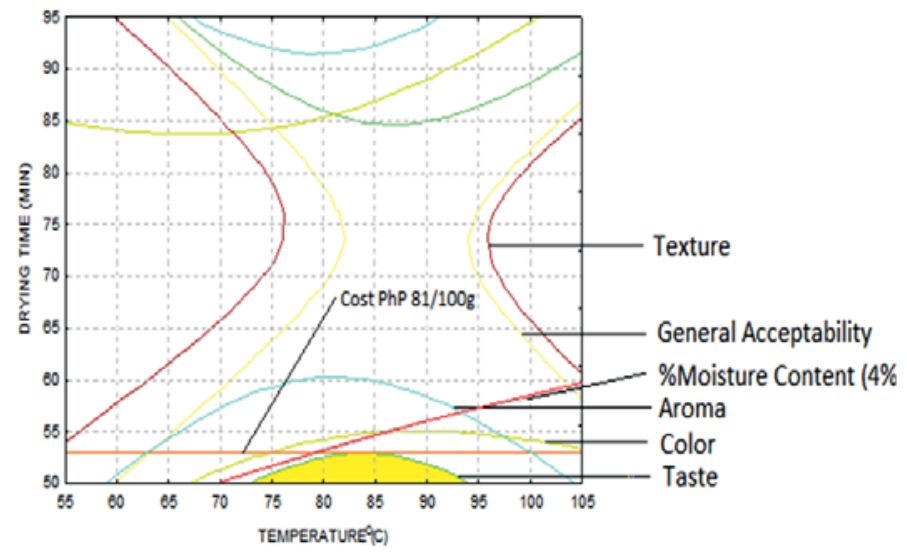

Figure 4. Superimposed contour plot at constant toasting (20min), with sensory acceptability scores $>7.0$ 


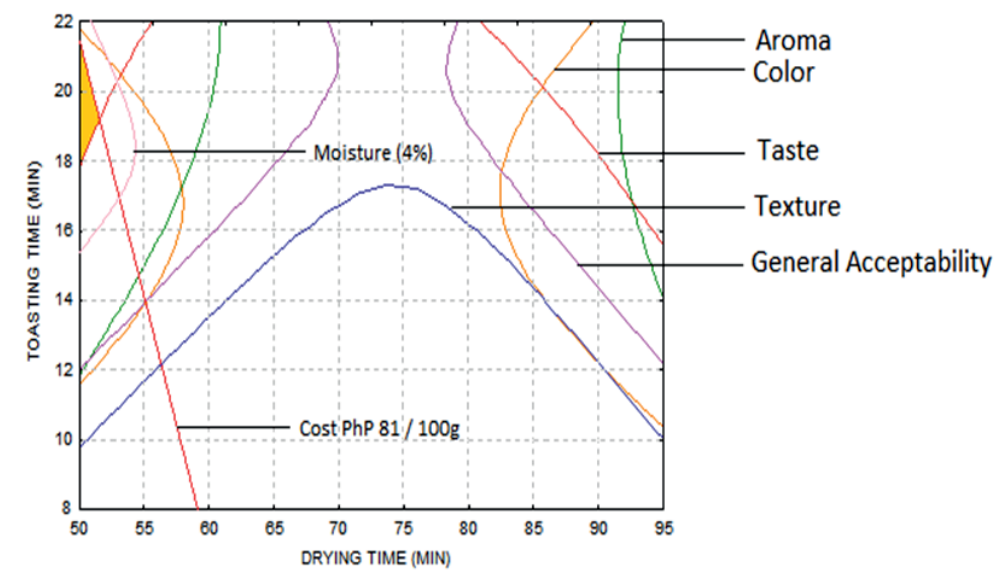

Figure 5. Superimposed contour plot at constant temperature $\left(80^{\circ} \mathrm{C}\right)$ with sensory acceptability scores $>7.0$.

Integrated plots showed that at constant toasting time for $20 \mathrm{~min}$. (Fig. 4), a combination of drying temperature from 75 to 90 and a drying time of 50 minutes will satisfy the shaded region. It is shown that the sensory parameter limiting the acceptability region is taste. At constant drying temperature at $80^{\circ} \mathrm{C}$ (Fig. 5), a combination of toasting time from 18 to 20 minutes and a drying time of 50 minutes will satisfy the shaded region. Similarly as shown in the figure, the limiting sensory parameter is taste. These results confirm that the taste attribute for sweetpotato flakes must be highly considered in succeeding studies.

Table 6. Optimum conditions for sweetpotato flake production and its corresponding predicted acceptability means

\begin{tabular}{cccccccccc}
\hline $\begin{array}{c}\text { Drying } \\
\text { Temp. } \\
\left({ }^{\circ} \mathrm{C}\right)\end{array}$ & $\begin{array}{c}\text { Drying } \\
\text { time } \\
(\mathrm{min})\end{array}$ & $\begin{array}{c}\text { Toasting } \\
\text { time } \\
(\mathrm{min} .)\end{array}$ & Color & Aroma & Taste & Texture & $\begin{array}{c}\text { Gen. } \\
\text { Acc. }\end{array}$ & $\begin{array}{c}\text { COST } \\
(\text { Php) }\end{array}$ & $\begin{array}{c}\% \\
\text { Moisture }\end{array}$ \\
\hline 75 & 50 & 20 & 7.10 & 7.53 & 7.06 & 9.16 & 7.85 & 79.11 & 3.52 \\
80 & 50 & 20 & 7.15 & 7.57 & 7.14 & 9.27 & 7.98 & 79.11 & 3.08 \\
80 & 50 & 18 & 7.24 & 7.49 & 7.01 & 9.14 & 7.87 & 77.77 & 3.03 \\
85 & 50 & 20 & 7.18 & 7.56 & 7.15 & 9.28 & 8.03 & 79.11 & 2.70 \\
90 & 50 & 20 & 7.20 & 7.50 & 7.10 & 9.19 & 8.02 & 79.11 & 2.36 \\
\hline
\end{tabular}


Quality Assessment of the Optimized Sweetpotato Flakes

\section{Physico-chemical characteristics}

Table 7 presents the physico-chemical and functional properties of the optimized sweetpotato flakes. Results show that a significant increase in TSS was observed in the final product after a series of heating was applied to sweetpotato puree. The final product has a TSS of $25.33{ }^{\circ}$ Brix. Heat application in purees did not result in increase in TSS value but when toasted into flakes, a significant increase in TSS was observed.

The bulk density of breakfast cereals is important in relation to their packaging requirements and the ability to float or sink when poured into milk (Sumithra and Bhattacharya, 2008). Bulk density is usually reported as "freely settled" or "tapped". When a material (e.g. powdered milk) is placed in a cylinder, it will have a particular bulk density (free settled); if the cylinder is disturbed, the product particles will move and usually settle close together ("tapped") resulting in a higher bulk density. Tapped density refers to the bulk density of the product after a specified compaction process usually involving vibration of the container. Results showed that the average "freely settled "bulk density for SP-Flakes is $13.80 \mathrm{lb} / \mathrm{ft}^{3}$ while for "tapped" density is $15.07 \mathrm{lb} / \mathrm{ft}^{3}$. These results show a small difference between the "freely settled" and "tapped" density allowing only minimal movement of flakes after compaction process.

Most dehydrated products are rehydrated at their final use (corn flakes, soups etc.) therefore it is important to know their compression behavior after rehydration. The rehydration characteristics of the materials are influenced by processing conditions, sample composition, sample preparation and detrimental effects occurring during drying or dehydration (Bhattiprolu 2004). Low rehydration ratio value is a cause of the material's low capacity to absorb water which may be a result of the deteriorative effects of prolonged drying on the microstructure of the material.

Table 7. Physico-chemical and functional properties of the optimized Sweetpotato flakes.

\begin{tabular}{cccclc}
\hline \multicolumn{2}{l}{ Total Soluble Solids (TSS) } & \multicolumn{2}{c}{ Bulk Density } & \multicolumn{2}{l}{$\begin{array}{l}\text { Rehydration } \\
\text { ratio }\end{array}$} \\
\hline $\begin{array}{c}\text { Puree } \\
\text { initial }\end{array}$ & $\begin{array}{c}\text { Puree } \\
\text { final }\end{array}$ & Product & $\begin{array}{c}\text { Freely } \\
\text { Settled }\end{array}$ & Tapped & \\
\hline $16.67^{\circ} \mathrm{Bb}$ & $17.87^{\circ} \mathrm{Bb}$ & $25.33^{\circ} \mathrm{Ba}$ & $\begin{array}{c}13.8 \\
\mathrm{lb} / \mathrm{ft} 3\end{array}$ & $\begin{array}{l}15.07 \\
\mathrm{lb} / \mathrm{ft} 3\end{array}$ & 3.57 \\
\hline
\end{tabular}

*For TSS, Mean values with the same letter are not significantly different at $p<0.05$. 
The general acceptability of the product evaluated was "6" (Table 8) which is described as "like slightly" in the 9-point Hedonic scale. Although the optimum conditions in processing sweetpotato flakes has been met, there is still a need in improving the sensory characteristics of the product especially in developing taste and obtaining a uniform crisp texture. Nevertheless, result obtained show potential of SP-30 for flake production.

Table 8. Descriptive and acceptability scores of optimized sweetpotato flakes

\begin{tabular}{ccc}
\hline Attributes & Description & Acceptability \\
\hline Color & dark yellow & like slightly (6) \\
Aroma & slightly perceptible & like slightly-like very much \\
& Slightly sweet, bland & like slightly (6) \\
Taste & crunchy and hard & like slightly (6) \\
Texture & dark yellow & like slightly (6) \\
Gen.Acceptability &
\end{tabular}

Note: Acceptability scores: 1 (dislike extremely) to 9 (like extremely)

\section{Sorption Isotherm}

Figure 6 shows the sorption isotherms derived from the experimental data. The plot of water activity against Equilibrium Moisture Content (EMC) is sigmoid in shape and is closely related to that of type II isotherm (BDDT classification) which, is said to be the typical sorption isotherm of most foods. The initial decrease in EMC with respect to water activity in the early stage may be attributed to the adjustment period or the time needed for the salt solution(s) to equilibrate. It should be noted that weight measurements started after a day the set-up was made which, may have not been enough for the environment inside the set-up to equilibrate.

\section{Fitting of data using BET and GAB sorption isotherm models}

\section{Brunauer-Emmettand Teller (BET)}

Figure 7 shows the BET isotherms using the calculated $C_{B}$ and $W_{m}$ values at each temperature setting. Water activity was plotted against the mass fraction of adsorbed water which was calculated using the formula:

$$
W=\left[C_{B} A_{w} /\left(1-A_{w}\right)\left[1+\left(C_{B}-1\right) A_{w}\right]\right] \times W_{m}
$$


Tan et al.

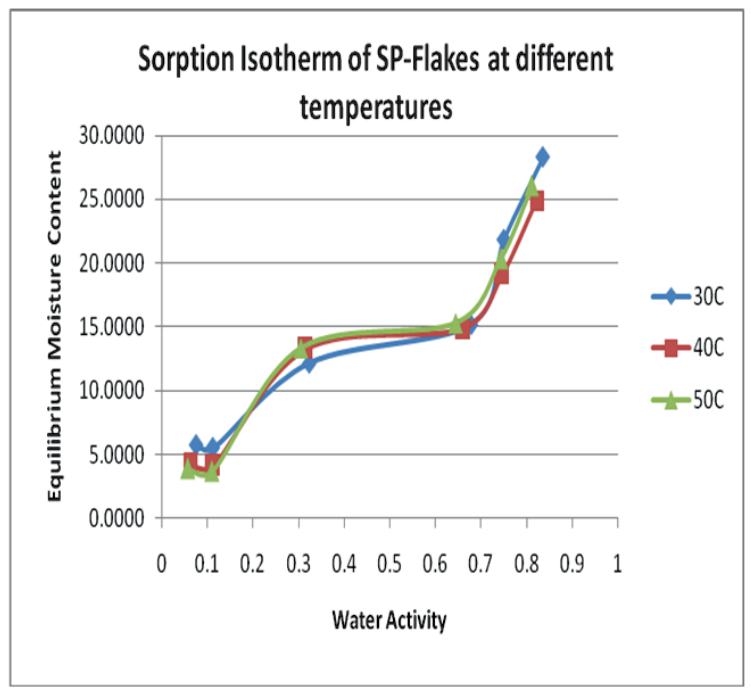

Figure 6. Sorption Isotherms of SP-flakes.

The isotherm derived is sigmoid in shape and can be perceived as type II according to BDDT classifications.

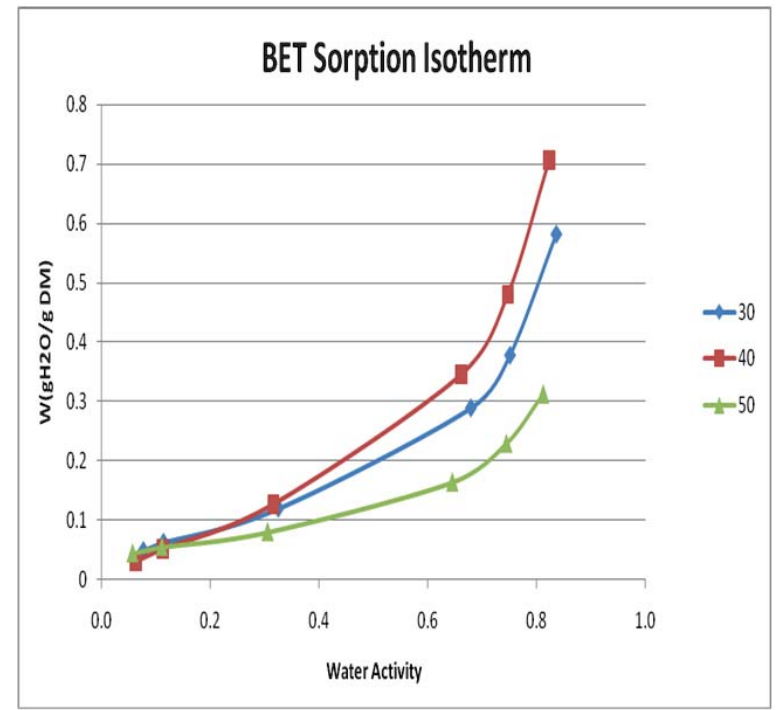

Figure 7. BET Sorption isotherms of SP-flakes. 
Sweetpotato flakes: Process Optimization and Moisture Adsorption

Guggenheim-Anderson de Boer (GAB)

Figure 8 shows the GAB isotherms using the calculated $\mathrm{C}_{\mathrm{G}}, \mathrm{W}_{\mathrm{mG}}$ and $\mathrm{k}$ values at each temperature setting. Water activity was plotted against the mass fraction of adsorbed water which was calculated using the formula:

$$
\mathrm{W}=\left[\mathrm{C}_{\mathrm{G}} \mathrm{kA} \mathrm{w}_{\mathrm{w}} /\left(1-\mathrm{kA}_{\mathrm{w}}\right)\left[1+\left(\mathrm{C}_{\mathrm{G}}-1\right) \mathrm{kA}_{\mathrm{w}}\right]\right] \times \mathrm{W}_{\mathrm{mG}}
$$

The isotherm derived is sigmoid in shape and it can further be noticed that at $30^{\circ} \mathrm{C}$ the isotherm is type II but for higher temperatures at 40 and $50^{\circ} \mathrm{C}$ the isotherm shifted to type I based on BDDT classifications.

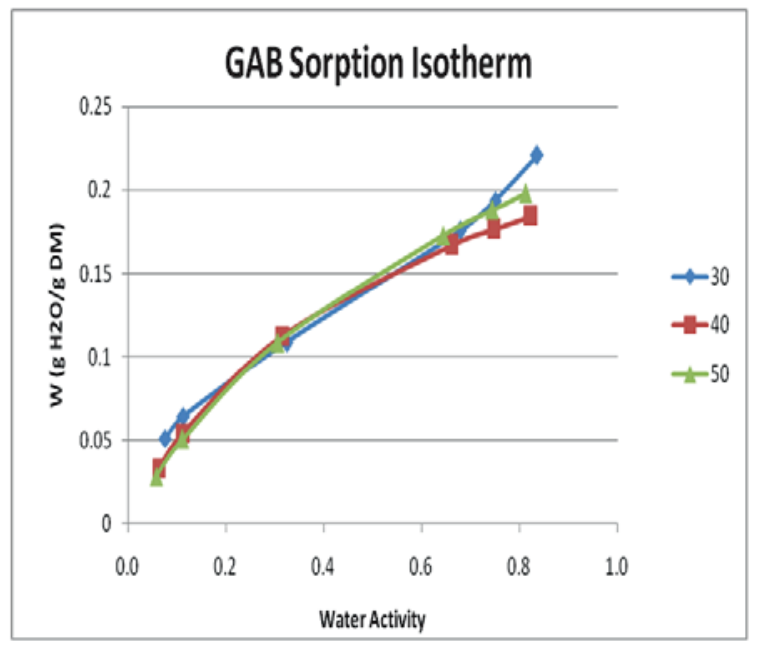

Figure 8. GAB Sorption isotherms of sweetpotato flakes.

Monolayer values of adsorbed moisture in the material is an important consideration in food processing. Several authors observed that the monolayer capacity of B.E.T is always less than G.A.B $\left(\mathrm{W}_{\mathrm{mB}}<\mathrm{W}_{\mathrm{mG}}\right)$ and that the energy constant derived from B.E.T is always greater than G.A.B $\left(\mathrm{C}_{\mathrm{B}}>\mathrm{C}_{\mathrm{G}}\right)$. This relationship for the experimental monolayer capacity of B.E.T and G.A.B at temperatures 30,40 and $50^{\circ} \mathrm{C}$, was observed to be true (Table 14). The third G.A.B constant $\mathrm{k}$ determines the profile of the isotherm at higher water activities. Results showed that at $30^{\circ} \mathrm{C}, \mathrm{k}=0.6555$ while for experimental set-up at 40 and $50^{\circ} \mathrm{C}$, $\mathrm{k}$ value is much lower. A lower value of $\mathrm{k}$ indicates a much less structured state of the sorbate in the layer following the monolayer (Timmerman, E. 2000). 
Table 9. Calculated BET and GAB parameters.

\begin{tabular}{cccccccc}
\hline \multirow{2}{*}{ Temperature } & \multicolumn{3}{c}{ B.E.T } & \multicolumn{4}{c}{ G.A.B } \\
\cline { 2 - 8 } & $\mathrm{Wm}_{\mathrm{B}}$ & $\mathrm{C}_{\mathrm{B}}$ & $\mathrm{R}^{2}$ & $\mathrm{Wm}_{\mathrm{G}}$ & $\mathrm{C}_{\mathrm{G}}$ & $\mathrm{k}$ & $\mathrm{R}^{2}$ \\
\hline $30^{\circ} \mathrm{C}$ & 0.09713 & 10.5628 & 0.9553 & 0.1046 & 16.6511 & 0.6555 & 0.8715 \\
$40^{\circ} \mathrm{C}$ & 0.1311 & 4.3720 & 0.6329 & 0.2447 & 24.2187 & 0.1020 & 0.8050 \\
$50^{\circ} \mathrm{C}$ & 0.0591 & 40.0492 & 0.8955 & 0.2224 & 10.4544 & 0.2403 & 0.6662 \\
\hline
\end{tabular}

Where:

$\mathrm{Wm}_{\mathrm{B}}=$ mass fraction of adsorbed water in the monolayer for B.E.T $\left(\mathrm{gH}_{2} \mathrm{O} / 100 \mathrm{~g}\right.$ dry matter)

$\mathrm{C}_{\mathrm{B}}=$ B.E. $\mathrm{T}$ constant

$\mathrm{Wm}_{\mathrm{G}}=$ mass fraction of adsorbed water in the monolayer for G.A.B $\left(\mathrm{gH}_{2} \mathrm{O} / 100 \mathrm{~g}\right.$ dry matter)

$\mathrm{C}_{\mathrm{G}} \quad=\mathrm{G} \cdot \mathrm{A} \cdot \mathrm{B}$ constant

$\mathrm{K}=$ constant

$\mathrm{R}^{2}=$ coefficient of determination

\section{CONCLUSIONS AND RECOMMENDATIONS}

Sweetpotatoes particularly SP-30 has high potential for flake production based on sensory acceptability results. Sweetpotato flakes can be produced using the process with the following optimum conditions for drying temperature $\left({ }^{\circ} \mathrm{C}\right.$ ) - drying time (min) - toasting time (min) respectively: 75-50-20, 80-50-20, 80-50-18, 85-50-20 and 90-50-20. Sorption isotherm of sweetpotato flakes was found to be type II in nature based on BDDT classifications.

Improve taste of sweetpotato flakes to enhance palatability and acceptability. It is recommended to use recent sorption isotherm analysis (e.g Proximate Equilibrium Cells, PEC) and to use other sorption isotherm equations with relation to food.

\section{REFERENCES}

AL-MUHATSEB, A. H., W.A.M. McMINN and T.R.A MAGEE. 2004. Water sorption isotherms of starch powders. Part 1: mathematical description of experimental data. Journal of Food Engineering 61: 297-307

AL-MUHATSEB, A. H. W.A.M. McMINN and T.R.A MAGEE. 2004. Water sorption isotherms of starch powders. Part 2: Thermodynamic characteristics. Journal of Food Engineering 62:135-142 
Sweetpotato flakes: Process Optimization and Moisture Adsorption

BLAHOVEC J., YANNIOTIS S. 2010. 'GAB' generalized equation as a basis for sorption spectral analysis. Czech J. Food Sci., 28: 345-354.

BARBOSA-CANOVAS, V. G., A.J. FONTANA Jr., S.J. SCHMIDT and T.P. LABUZA. 2007. Water Activity in Foods. Pp. 109-173

BHATTIPROLU, S. 2004. Color, texture and rehydration characteristics of ohmically treated sweet potatoes. Masteral Dissertation, Master of Science in Biological and Agricultural Engineering, Louisiana State University and Agricultural and Mechanical College.

ELTOUM, Y. and BABIKER, B. 2013. Changes in Antioxidant content, Rehydration ratio and browning index during storage of edible surface coated and dehydrated tomato slices. Journal of Food Processing and Preservation: 1 - 10

ESTILLORE, G. 2009. Food S \& T Roadmap. Paper presented during the Regional Consultation (Visayas Cluster) on Science and Technology Roadmap Forum: Regional Roles and Perspectives. February 17, 2009. Cebu Grand Hotel, Cebu Capitol Complex, North Escario St., Cebu City.

FERRAREN E. 2013. National Root Crop Cooperation Testing Program on sweetpotato. PhilRootcrops, VSU, Baybay, Leyte

GROSS, M. O. and N. M. RAS, 1977. Flow Characteristics of Sweetpotato Puree as Indicators of Dehydrated Flake Quality. k. 42(4): 924-926.

GREENSPAN, L. 1977. Humidity fixed points of binary saturated aqueous solutions. Journal of Research of the National Bureau of Standards - A. Physics and Chemistry Vol. 81 A, No.1

HOOVER M. W. and L. J. KUSHMAN. 1966. Influence of Raw Product Storage Treatments o nthe Quality of sweetpotato Flakes. Proc. Am. Soc. Hort. Sci. (In Press). Cited in "An Enzyme-Activation Process for Producing Sweetpotato Flakes, M. W. Hoover, Fd. Tech. 21:322-325.

HOOVER, M. W. 1966. An Enzyme Process for Producing Sweetpotato Flakes from Starchy and Uncured Roots. Fd. Tech. (1):84-87. 
Tan et al.

HOUSSEIN, T. A. 2007. Water sorption isotherms of Libyan date paste. Thesis: Master of Science in Food Engineering. Pp. 1- 66

KAYMAK-ERTEKIN, F. and GEDIK, A. 2004. Sorption isotherms and Isosteric heat of sorption for grapes, apricots, apples and potatoes, 37: 429-438

KIRANOUDIS, C. T. et. al. 1993. Equilibrium Moisture Content and Heat of Desorption of Some Vegetables. Journal of Food Engineering 20: 55-74

LIENDO-CARDENAS, M. et. al. 2000. Sorption Isotherm Equations of Potato Flakes and Sweet Potato Flakes. Braz.J. Food Technol., 3:53-57

LIENDO-CARDENAS M., ZAPATA-NORENA C. P. and BRANDELLI A. 2000. Sorption Isotherm Equations of Potato Flakes and Sweet Potato Flakes. Brazilian J Fd Tech 3:53-57

LEWICKI, PIOTR P. 1998. Some remarks on rehydration of dried foods. Journal of Food Engineering 36: 81 - 87

LOURDIN, D. 2005. Physical and sensory evaluation of cornflakes crispness. Journal of Texture Studies 36: 93 -118

POCSON, J. W. 2005. Desorption Isotherms of Abaca Fibers. Undergraduate Thesis: Bachelor of Science in Agricultural Engineering. Pp. 5-29

SUMITHRA B. and BHATTACHARYA, S. 2008. Toasting of corn flakes: product characteristics as a function of processing conditions. Journal of Food Engineering 88: 419 - 428

SPADARO, J. J., J. I. WADSWORTH, G. M. ZIEGLER, A. S. GALLO and S. P. KOLTUN. 1967. Instant Sweetpotato Flakes - Processing Modifications Necessitated By Varietal Differences. Fd. Tech. (3A):326-330.

SAMAPUNDO, S. et.al. 2007. Sorption isotherms and Isosteric heats of sorption of whole yellow dent corn. Journal of Food Engineering 79: $168-175$ 
Sweetpotato flakes: Process Optimization and Moisture Adsorption

TIMMERMANN, E. O. et. al. 2001. Water sorption isotherms of foods and foodstuffs: BET or GAB parameters? Journal of Food Engineering 48:19-31

WADSWORTH, J. I., S. P. KOLTUN, A. S. GALLO, G. M. ZIEGLER and J. J. SPADARO. 1966. Instant Sweetpotato Flakes: Factors Affecting Drying Rate on Double-Drum Dryer. Fd. Tech. (6):111-114. 